\title{
Taktyka i metody przeprowadzania dowodów z osobowych źródeł dowodowych. Metody dozwolone oraz niedozwolone
}

\author{
Tactics and methods for taking of evidence from the personal \\ sources of evidence. Authorised and prohibited methods
}

\begin{abstract}
Streszczenie:
Celem każdego postępowania karnego jest wykrycie prawdy materialnej w oparciu o ustalenia faktyczne, które dokonywane są na podstawie i dzięki zgromadzonemu materiałowi dowodowemu. Jednym ze sposobów przeprowadzenia dowodu jest przesłuchanie, które uważa się za najważniejsze źródło dowodu w procesie karnym. Przeprowadzając taki dowód, należy nie tylko zachować szczególną ostrożność oraz rozwagę, ale także stosować właściwą taktykę oraz metodę przeprowadzenia dowodu. W niniejszym artykule omówiono istotę taktyki przesłuchania, a także zaprezentowano klasyfikację metod przesłuchania.
\end{abstract}

Słowa kluczowe: materiał dowodowy, źródła osobowe, metody dozwolone i niedozwolone

\footnotetext{
Abstract:

The aim of every criminal proceedings is to uncover the material truth on the basis of statements of fact which are performed on the grounds of collected evidence. One of the methods of examination of the evidence is hearing which is claimed to be the most crucial source of evidence in the criminal procedure. When carrying out the before-mentioned evidence, not only the utmost care ought to be maintained, but also the right tactic and method of examination of the evidence should be applied.

The presented article discusses the matter of hearing and classification of hearing methods as well.
} 
Małgorzata Zawartka - Taktyka i metody przeprowadzania...

Keywords: collected evidence, personal sources, permitted and prohibited methods of examination

\section{Wstęp}

Przesłuchanie jest podstawową metodą przeprowadzenia dowodów z osobowych źródeł dowodowych. Pozwala na przeprowadzenie dowodów z wyjaśnień oskarżonego, zeznań świadków czy zeznań biegłego ${ }^{1}$. Ze względu na znaczną liczbę osobowych źródeł dowodowych, które pojawiają się w toku procesu karnego, to właśnie przesłuchanie jest najczęściej wykorzystywaną metodą przeprowadzenia dowodu.

Przesłuchanie opiera się na ogólnych regułach bez względu na to, czy jest prowadzone na etapie postępowania przygotowawczego czy też w toku postępowania głównego. Prawidłowość przeprowadzenia przesłuchania, kwestia pozyskania logicznych i wartościowych relacji o zdarzeniu stanowiącym przedmiot procesu karnego zależy od wielu czynników, wśród których wyróżnia się obok reguł procesowych także przyjęte taktyki przesłuchania ${ }^{2}$.

Procedury prawne związane z trybem prowadzenia przesłuchań są precyzyjnie określone w Kodeksie postępowania karnego (dalej: k.p.k.), a w skróconej formie także w każdym istotniejszym opracowaniu z zakresu psychologii sądowej ${ }^{3}$.

Metody prowadzenia przesłuchania, a także warunki ważności przeprowadzonego przesłuchania zostały sformułowane w art. 171 k.p.k., który gwarantuje osobie przesłuchiwanej prawo do swobodnej wypowiedzi, a także zawiera upoważnienia stron, obrońców, biegłych i pełnomocników do zadawania pytań. Ponadto zakazuje zadawania pytań, które mogą sugerować przesłuchiwanemu odpowiedź, wska-

\footnotetext{
${ }^{1}$ K. Marszał (red.), Proces karny, Katowice 2005, s. 268.

2 Z. Niezgoda, Kryminalistyczne aspekty przesłuchania świadka , „Prokuratura i Prawo" 2007, nr 2, s.76.

3 Z. Marten, Psychologia zeznań, Warszawa 2012, s. 64.
} 
zuje niedopuszczalne metody przesłuchiwania, sytuacje, w których organ procesowy może uchylić pytanie, a także określa, jakie wypowiedzi nie mogą zostać wykorzystane jako dowód w sprawie.

Zgodnie $\mathrm{z}$ art. $171 \S 1$ k.p.k. przesłuchanie jest prowadzone według ustalonego porządku, który zakłada, że pytania, które zmierzają do uzupełnienia, wyjaśnienia i kontroli odebranych zeznań, można zadawać dopiero po spontanicznej wypowiedzi. Kolejność jest nakazana ustawą i powinna być przestrzegana ${ }^{4}$.

\section{Metody oraz taktyka prowadzenia przesłuchań}

W Polsce obowiązuje tzw. mieszana metoda prowadzenia przesłuchań, która opiera się na swobodnej relacji osoby przesłuchiwanej i późniejszym zadawaniu ukierunkowanych pytań, zmierzających do kontroli złożonych zeznań, wyjaśnień bądź oświadczeń ${ }^{5}$. Pytania kierowane do osoby przesłuchiwanej zadaje się w sposób bezpośredni, chyba że organ przesłuchujący zarządzi inaczej. (art. $171 \S 2$ k.p.k.)

Jak wynika z badań prowadzonych przez J. Stanika, najbardziej kompletne wypowiedzi uzyskuje się $\mathrm{w}$ trakcie przesłuchania prowadzonego metodą krzyżową, a najmniej kompletne w toku swobodnej relacji ${ }^{6}$. Jednak to właśnie swobodna relacja pozwala na pozyskanie najdokładniejszych, zawierających najmniejszą liczbę błędów zeznań bądź wyjaśnieńn ${ }^{7}$ Badania potwierdziły zatem trafność stosowanej w Polsce metody mieszanej, która opiera się na wyeliminowaniu pytań sugerujących odpowiedź oraz umożliwieniu swobodnej wypowiedzi odnoszącej się do faktów związanych z przebiegiem zdarzenia będącego przedmiotem toczącego się postępowania karnego.

\footnotetext{
${ }^{4}$ K. Marszał (red.), Proces karny, dz. cyt., s. 268.

${ }^{5}$ A. Gadomska-Radel A., Przesłuchanie dziecka jako ofiary i świadka przestępstwa w procesie karnym, Warszawa 2015, s. 210.

6 Tamże s. 211.

7 V. Kwiatkowska-Darul, Przesłuchanie małoletniego świadka $w$ polskim procesie karnym, Toruń 2007, s. 207.
} 
Małgorzata Zawartka - Taktyka i metody przeprowadzania...

Wyłączenie swobody wypowiedzi osoby przesłuchiwanej, które jest gwarantowane na podstawie wspomnianego art. 171 k.p.k., może wynikać zarówno z naturalnych warunków przesłuchania, jak i stosowania dodatkowych środków oddziaływania na osobę przesłuchiwaną ${ }^{8}$ Naturalnymi warunkami, które wyłączają bądź ograniczają swobodę wypowiedzi, są m.in. wielogodzinne przesłuchiwania osoby, które przekładają się na jej wyczerpanie bądź przesłuchiwanie osoby, która odczuwa ból, głód lub jest spragniona.

Zgodnie z obowiązującymi przepisami zakazuje się stosowania dodatkowych metod i środków oddziaływania na osobę przesłuchiwaną. Zabronione jest wpływanie na wypowiedź osoby przesłuchiwanej groźbą, przymusem, hipnozą. Nie wolno stosować w stosunku do przesłuchiwanego środków chemicznych lub technicznych, które mogą oddziaływać na jej stan psychiczny (art. $171 \S 5$ k.p.k.)

Ustawa przewiduje możliwość konfrontacji osób przesłuchiwanych, co pozwala na wyjaśnienie sprzeczności wynikających ze złożonych zeznań. Możliwość konfrontacji jest wyłączona w odniesieniu np. do świadka anonimowego (art. 172 k.p.k.).

Zgodnie z art. 174 k.p.k. dowodu z wyjaśnień oskarżonego bądź zeznań świadka nie wolno zastępować treścią pism, zapisków czy też notatek urzędowych.

Za formę przesłuchania przyjmuje się okazanie osoby lub rzeczy, które służą ich rozpoznaniu. Osobę lub rzecz okazuje się osobie przesłuchiwanej. Okazanie najczęściej stosuje się w przypadku przesłuchania świadka, któremu okazuje się wizerunek konkretnej osoby bądź utrwaloną formę tego wizerunku, np. w postaci fotografii, filmu, rysunku.

Okazanie powinno być przeprowadzone w sposób, który uniemożliwi sugestię, o czym mowa w art. $173 \S 1$ k.p.k., a osoba okazywana powinna znajdować się w grupie obejmującej co najmniej cztery osoby (art. 173 § 3 k.p.k.).

\footnotetext{
8 K. Marszał (red.), Proces karny, dz. cyt., s. 268.
} 
W większości spraw karnych informacje pozyskane od osobowych źródeł dowodowych stanowią o sile zgromadzonego materiału dowodowego, są istotnymi wskazówkami do podjęcia kolejnych czynności wykrywczych, stanowią ważne ogniwo w rozległym łańcuchu dowodów ${ }^{9}$.

W przesłuchaniu uczestniczą dwie strony - strona odbierająca zeznania bądź wyjaśnienia, oraz osobowe źródło dowodowe.

Jest to proces komunikacji interpersonalnej, w którym pomiędzy stronami zachodzi wzajemne oddziaływanie - przekaz informacji zarówno o charakterze werbalnym, jak i niewerbalnym.

Przyjmuje się, że osoba prowadząca przesłuchanie powinna posiadać wiedzę z zakresu postępowania karnego, psychologii oraz kryminalistyki, wyróżniać się podzielnością uwagi, skrupulatnością i empatią.

Znajomość psychologii jest równie istotna, co znajomość kryminalistyki, pozwala bowiem zrozumieć i rozpoznać procesy psychiczne przebiegające u osoby przesłuchiwanej.

Na przebieg przesłuchania i jego finalny efekt mają wpływ uczestniczące w nim strony, istotną rolę odgrywa ich wzajemna ocena, prezentowane postawy, stan psychiczny, oczekiwania, a także cele, które zamierza osiągnąć każda ze stron ${ }^{10}$.

Celem każdego przesłuchania jest pozyskanie jak najpełniejszej informacji o osobach, zdarzeniach, miejscach, faktach, które mogą okazać się przydatne do ustalenia prawdy obiektywnej ${ }^{11}$. W zależności od strony uczestniczącej w przesłuchaniu, jak już wspomniano, wyróżnia się różne cele poza wymienionym celem ogólnym prowadzonego przesłuchania.

Osoba prowadząca przesłuchanie, odbierająca zeznania bądź wyjaśnienia koncentruje się na pozyskaniu możliwie jak największej liczby rzetelnych i wiarygodnych informacji o konkretnym wydarzeniu. Stro-

\footnotetext{
${ }^{9}$ Z. Niezgoda, Kryminalistyczne aspekty..., dz. cyt. s. 76.

10 Tamże.

11 M. Cieślak, Polska procedura karna. Podstawowe założenia teoretyczne, Warszawa 1984, s. 49.
} 
Małgorzata Zawartka - Taktyka i metody przeprowadzania...

nie przesłuchiwanej nie można już tak jasno przypisać zamiarów, jakimi się kieruje i tym samym celów, jakie planuje osiągnąć. Może mieć bowiem na celu umyślne wprowadzenie w błąd poprzez zeznanie nieprawdy lub zatajenie informacji istotnych ${ }^{12}$, dzięki czemu postępowanie zostanie skierowane na niewłaściwy tor. Poza wprowadzaniem w błąd organu przesłuchującego dodatkowym utrudnieniem jest składanie zeznań, które nie wnoszą nic do sprawy.

Dla osoby prowadzącej przesłuchanie w osiągnięciu wyznaczonych istotne jest zastosowanie właściwej taktyki.

Taktyka przesłuchania to ogół sposobów, metod i środków. Obejmuje ogólny zbiór wskazówek i związanych z nimi czynności, które dotyczą nie tylko samego przesłuchania, w ścisłym znaczeniu tego słowa, ale także procedur następujących przed przystąpieniem do przesłuchania. Przepisy prawa nie zawierają szczegółowych wskazówek regulujących poszczególne czynności związane z prowadzeniem przesłuchania ${ }^{13}$. Problematyką tą zajmuje się szczegółowo kryminalistyka i psychologia zeznań.

Rozdział dziewiętnasty k.p.k. co prawda normuje wiele kwestii dotyczących dowodów, których źródłem są m.in. podejrzany i świadek, natomiast nie wyjaśnia, jak należy przeprowadzić przesłuchanie, aby dostarczyć jak najbardziej rzetelnych i kompletnych dowodów, istotnych przy podejmowaniu przyszłych decyzji procesowych ${ }^{14}$. Takie wytyczne i wskazówki znajdują się natomiast w licznych opracowaniach kryminalistycznych, poświęconych metodom przesłuchiwania osobowych źródeł dowodowych.

Z kryminalistycznego punktu widzenia najbardziej wymagające są szczególne formy przesłuchania, takie jak okazanie czy wizje lokalne. Każdy element okazania czy wizji lokalnej wymaga starannego obmy-

12 E. Gruza, M. Goc, J. Moszczyński, Kryminalistyka - czyli rzecz o metodach śledczych, Warszawa 2008, s. 109.

13 B. Hołyst, Psychologia kryminalistyczna, Warszawa 2004, s. 936.

14 J. Gurgul, Znaczenie taktyki kryminalistycznej $w$ realizacji zasad postępowania karnego, „Problemy Kryminalistyki” 1985, nr 168, s. 189. 
ślenia pod względem taktycznym. Wybór odpowiedniej taktyki przekłada się na wynik przeprowadzonych czynności dowodowych.

Zindywidualizowana taktyka przesłuchiwania przynosi najlepsze rezultaty, co podkreślał znany sędzia i szwajcarski teoretyk Jean Graven. Podkreślał on, że sposób, w jaki prowadzi się samo przesłuchanie, wywiera znaczący wpływ na wartość pozyskanego materiału dowodowego ${ }^{15}$. Każdy świadek musi być traktowany indywidualnie, co przekłada się na indywidualny dobór metody przesłuchiwania.

E. Gruza definiuje metody przesłuchania jako świadomie wybrany i zastosowany sposób postępowania, mający na celu pozyskanie wszechstronnych i jak najkompletniejszych zeznań od osoby przesłuchiwanej16.

Jak zauważa W. Chudy, metoda to sposób działania (oddziaływania na kogoś, kierowania czyimś postępowaniem), który jest powtarzalny i systematycznie określony ${ }^{17}$.

Przepisy k.p.k. nie posługują się terminologią metody przesłuchania, jednak zasadnicze znaczenie w tej kwestii ma art. $171 \S 1$ k.p.k. Literatura przedmiotu najczęściej do metod przesłuchania zalicza elementy zawarte właśnie $\mathrm{w}$ tym przepisie ${ }^{18}$.

Metody postępowania zgodne z art. 171 k.p.k. to kombinacje etapów składania zeznań i wyjaśnień zmierzających do osiągnięcia celów przesłuchania.

Każde przesłuchanie, które może zostać uznane za spełniające kryteria metody przesłuchania, musi być wolne od dyskwalifikujących je wad w postaci wymienionych w ustawie naruszeń swobody wypowiedzi, a także od wad, które co prawda nie eliminują ważności przesłuchania, ale eliminują jego jakość- nastawionej na uzyskanie szczerej,

15 Tamże, s. 190.

${ }^{16}$ E. Gruza, Ocena wiarygodności zeznań świadków w procesie karnym. Problematyka kryminalistyczna, Kraków 2003, s. 285.

17 W. Chudy, Kłamstwo jako metoda. Esej o społeczeństwie i kłamstwie, Warszawa 2007, s. 72.

18 R. Kaczor, Niedozwolone sposoby przesłuchania, „Prokuratura i Prawo” 2009, nr 3, s. 113. 
Małgorzata Zawartka - Taktyka i metody przeprowadzania...

zgodnej z prawdą relacji, a nie jakiejkolwiek relacji osoby przesłuchiwanej ${ }^{19}$.

W pracy Der Realitätsgehalt von Zeugenaussagen autor Arne Trankell charakteryzował zeznania jako ekspresję właściwych konkretnej jednostce cech. Twierdził, że:

\begin{abstract}
zachowanie osoby przesłuchiwanej jest w każdym momencie produktem interakcji z osobą przesłuchującą, jest pochodną aktualnych dyspozycji behawioralnych i warunków środowiskowych, w których te dyspozycje są realizowane 20 .
\end{abstract}

Odwołując się do słów A. Trankella, można stwierdzić, że zenanie jest warte tyle, ile zastosowana metoda, dostosowana indywidualnie do każdego świadka.

\title{
Klasyczne metody prowadzenia przesłuchania
}

W literaturze wyróżnia się trzy podstawowe metody przesłuchania, które opierają się na swobodnej wypowiedzi osoby przesłuchiwanej i zadawaniu pytań przez osobę przesłuchującą ${ }^{21 .}$

Pierwsza metoda to tzw. metoda swobodnej relacji, określana skrótowo metodą SR. W tej metodzie osoba przesłuchiwana zdaje swobodną relację co do faktów dotyczących zdarzenia będącego przedmiotem postępowania karnego. Dopuszczalne jest zadawanie ogólnych pytań, które dotyczą zdarzenia, mających na celu pobudzenie intencji świadka do nieskrępowanego opisu i relacjonowania.

Kolejna metoda, metoda pytań ukierunkowanych (PU), opiera się na celowym kierowaniu przebiegiem przesłuchania, tak by możliwe było pozyskanie jak najdokładniejszych i najkompletniejszych informacji. Osoba przesłuchująca zadaje konkretne pytania, które wymagają podania szczegółowej i uściślonej odpowiedzi.

\footnotetext{
19 Tamże s. 115.

20 Z. Marten, Psychologia zeznań, dz. cyt., s. 104.

21 E. Gruza, Ocena wiarygodności..., dz. cyt., s. 283.
} 
Ostatnia z najczęściej stosowanych metod - metoda pytań krzyżowych (CE od ang. cross examination) - bazuje na bezpośrednim zadawaniu pytań osobie przesłuchiwanej w taki sposób, by uwypuklić dotychczasowe braki, nieścisłości, niekonsekwencje wypowiedzi. Metoda dopuszcza stosowanie różnego rodzaju presji i nacisków, zarówno merytorycznych jak i formalnych. Przesłuchujący może manipulować sposobem, w jaki zadaje pytania, przekazami pozawerbalnymi, a także sytuacją towarzyszącą przesłuchaniu. Część metod przesłuchania krzyżowego jest kwestionowana z etycznego punktu widzenia

Od ponad osiemdziesięciu lat $\mathrm{w}$ teorii i praktyce psychologii zeznań stosowana jest klasyfikacja kryteriów wartości zeznania stworzona przez Wiliama Sterna. W wyniku przeprowadzonych badań Stern określił wartość poszczególnych metod przesłuchania. W badaniach posłużył się trzema miarami wartości zeznań, takimi jak ich kompletność, dokładność i ostrożność. Kompletność zeznań wyznacza się w oparciu o liczbę informacji zawartą w wypowiedzi, bez względu na to, czy informacje okazały się użyteczne ze względu na badane zdarzenie. Dokładność mierzy się liczbą informacji przydatnych do wykorzystania w odtworzeniu logiki zdarzenia. Ostrożność ustalana jest w oparciu o odpowiedzi udzielane w formie „nie wiem”, „nie pamiętam", bądź brak jakiejkolwiek odpowiedzi. W odpowiedziach ostrożnych osoba przesłuchiwana często zastanawia się przed dłuższą chwilę, zanim w ogóle udzieli jakiejkolwiek odpowiedzi.

Tabela 1. Wyznaczniki wartości zeznań wg W. Sterna

\begin{tabular}{|c|c|c|c|}
\hline $\begin{array}{c}\text { Wskaźnik ze- } \\
\text { znania }\end{array}$ & SR & PU & CE \\
\hline Kompletność & Przeciętna & Niska & Bardzo niska \\
\hline Dokładność & Niska & Przeciętna & Bardzo niska \\
\hline Ostrożność & Bardzo niska & Wysoka & Bardzo wysoka \\
\hline
\end{tabular}

Źródło: Z. Marten, Psychologia zeznań, Warszawa 2012, s. 110. 
Małgorzata Zawartka - Taktyka i metody przeprowadzania...

\section{Nowe metody prowadzenia przesłuchania}

Obok najczęściej wykorzystywanych metod klasycznych w literaturze wymienia się także metody nowsze, takie jak metoda deiktyczna i metoda symultaniczna.

Metoda deiktyczna to tzw. metoda przez pokaz, która opiera się na zaprezentowaniu, zademonstrowaniu przez świadka faktu, którego nie jest w stanie opisać słownie.

Metoda ta wykorzystywana jest najczęściej w przypadku osób o niskiej kulturze słownej, osób przestraszonych, przybierających postawę obronną, mało kompetentnych w konkretnej dziedzinie ${ }^{22}$. Wykorzystywana jest przy przesłuchaniu osób nieletnich, rzadziej w przypadku osób starszych. Jedną z jej największych wad jest konieczność zapisania w protokole zachowania demonstrowanego przez osobę przesłuchiwaną lub jego rejestracji na nośnikach cyfrowych.

Jedną z szeroko komentowanych metod deiktycznych jest przesłuchanie z wykorzystaniem lalek anatomicznych. Lalki te stosuje się najczęściej w trakcie przesłuchania dzieci, które były ofiarami molestowania seksualnego. Stosowanie lalek jest w literaturze powodem wielu sporów ${ }^{23}$.

Lalki, jak twierdzą ich przeciwnicy, są brzydkie, szokujące, wręcz przerażające dla dziecka. Brzydota lalek wiąże się z ryzykiem szoku poznawczego, jeżeli w którymś momencie badania lalka zostanie pozbawiona ubioru.

Ponadto przesłuchanie prowadzone $\mathrm{z}$ wykorzystaniem lalek anatomicznych może sugerować dziecku konkretną odpowiedź lub jej kierunek. Metoda ta nie jest odpowiednio standaryzowana, nie ma jednej instrukcji jej stosowania ${ }^{24}$.

22 Z. Marten, Psychologia..., dz. cyt., s.105.

${ }^{23}$ L. D. Reed, Podatność dzieci na sugestię : ustalenia badawcze i ich implikacje dla przesłuchiwania dzieci, „Dziecko krzywdzone. Teoria. Badania. Praktyka” 2004, nr 6, s. 26.

24 Z. Marten, Psychologia..., dz. cyt., s. 108. 
Specjalną sytuacją, w której zeznania odbiera się metodą deiktyczną, jest także rozpoznanie przez osobę przesłuchiwaną zapamiętanej twarzy metodą rekonstrukcji za pomocą tzw. portretu pamięciowego $^{25}$.

Metoda symultaniczna charakteryzuje się pytaniem jednocześnie kilku osób przesłuchiwanych przez jednego przesłuchującego. W polskim systemie prawnym odpowiednikiem metody symultanicznej jest w pewnym sensie konfrontacja, a także dochodzeniowe formy czynności, takie jak np. eksperyment kryminalistyczny czy odtworzenie.

Wadą metody symultanicznej jest ryzyko wystąpienia zjawiska ujednolicenia opinii świadków, którzy występują zbiorowo. Ewentualną zaletą jest świeżość pozyskanych informacji, spontaniczność relacji, które niesie ze sobą kolejne ryzyko związane z emocjonalnością przekazu26.

Metoda symultaniczna jest szeroko stosowana w praktyce, ale w teorii psychologii zeznań odnotowana jest jedynie w sposób symboliczny27.

\section{Techniki przesłuchania}

Podział technik przesłuchań odpowiada podziałowi przestępstw, które mogą być popełniane z pobudek racjonalnych (np. kradzież, oszustwo), bądź emocjonalnych (np. udział w bójce, zabójstwo).

Podział technik nie jest metodologicznie poprawny, ale nie można było uzyskać go według innych kryteriów, w tym jako metody właściwej dla świadka czy podejrzanego ${ }^{28}$. Przesłuchanie świadka i podejrzanego zwykle różni się pod wieloma względami, ale w przypadku

${ }^{25}$ J. Kaźbińska, Kryminalistyczna użyteczność psychologicznych badań nad portretami pamięciowymi, [w:] B. Gulla, I. Niewiadomska, M. Wysocka-Pleczyk (red.), Białe plamy w psychologii sq̨dowej, Kraków 2010, s. 147.

26 Z. Marten, Psychologia..., dz. cyt., s. 106.

27 M. Ciosek, Psychologia sq̨dowa i penitencjarna, Warszawa 2001, s. 97.

28 W. Pasko-Porys, Przesłuchiwanie i wywiad. Psychologia kryminalistyczna, Warszawa 2007, s. 111. 
Małgorzata Zawartka - Taktyka i metody przeprowadzania...

przesłuchania nieszczerego świadka najczęściej upodabnia się ono do przesłuchania podejrzanego.

Wśród technik racjonalnych wyróżniamy: technikę wykazywania związku ze zdarzeniem, dawkowania dowodów, kumulatywnego ujawniania dowodów oraz technikę refleksji logicznej.

Technika wykazywania związku ze zdarzeniem opiera się na przedstawieniu osobie przesłuchiwanej dowodu, który świadczy o jej zetknięciu się z okolicznościami sprawy. T. Hanausek określa tę technikę jako technikę przypominania ${ }^{29}$. W ramach tej techniki możliwe jest wykorzystanie etycznego podstępu.

Technika dawkowania dowodów wiąże się wykazaniem związku ze zdarzeniem. Stosuje się ją najczęściej wtedy, gdy podejrzany lub świadek nie chce udzielić wyjaśnień lub złożyć zeznań. Technika ta wymaga zgromadzenia odpowiedniego materiału, stanowiącego podstawę do skonstruowania i zadawania pytań.

Kumulatywne ujawnienie dowodów nazywane jest także techniką czołowego natarcia. B. Hołyst określa tę technikę jako jednorazowe zaprezentowanie posiadanych dowodów ${ }^{30}$. Zastosowanie techniki kumulatywnego ujawniania dowodów wymaga uprzedniego przygotowania, tak by móc zaprezentować osobie przesłuchiwanej właściwy materiał dowodowy.

Technika refleksji logicznej została najszerzej omówiona przez E. Gruzę. Technika ta opiera się na uzyskaniu szczerych wyjaśnień w drodze pogrążania osoby przesłuchiwanej poprzez wykazanie jego nieszczerości i sprzeczności występujących w jego kłamliwych wypowiedziach ${ }^{31}$.

Przy zastosowaniu refleksji logicznej w dojściu do podjęcia decyzji o odstąpieniu od kłamliwych i nieszczerych zeznań najważniejszą rolę odgrywa motywacja intelektualna osoby przesłuchiwanej. Kłamiący uświadamia sobie prędzej czy później, że dalsze składanie fałszywych

29 T. Hanausek, Braki pamięciowe w zeznaniach świadka, „Problemy Kryminalistyki” 1969, nr 82, s. 715.

30 B. Hołyst, Kryminalistyka, Warszawa 2004, s. 1123.

31 E. Gruza, Ocena wiarygodności..., dz. cyt., s. 288. 
zeznań bądź wyjaśnianie nie ma sensu, gdyż sam dostarczył przesłuchującemu dowodów własnej nieszczerości ${ }^{32}$.

Druga grupa technik to tzw. techniki emocjonalne, wśród których wyróżnia się: technikę perswazji, bezpośredniego wykazania kłamstwa oraz technikę odtwarzania przebiegu zdarzeń.

Pierwsza z technik emocjonalnych, tj. technika perswazji, opiera się na przekonaniu osoby przesłuchiwanej, że łączy ją z przesłuchującym wspólny interes ${ }^{33}$. Technika zakłada odwoływanie się do pewnych wartości moralnych i postaw obywatelskich prezentowanych przez konkretną osobę. Najczęściej wykorzystywana jest przy przesłuchiwaniu świadków zdarzeń.

Kolejna $\mathrm{z}$ technik emocjonalnych, tj. bezpośrednie wykazywanie kłamstwa, jest możliwa do zastosowania w sytuacjach, w których uzyskano wcześniej prawdziwe informacje nt. faktów wynikających z fałszywie złożonych zeznań ${ }^{34}$. Technika pozwala na szybką prezentację prawdziwego dowodu, który udowadnia kłamstwa osoby przesłuchiwanej. Technika ta może stanowić szczególną wersję metody refleksji logicznej. Różni ją element zaskoczenia, który ma charakter emocjonalny35.

Odtwarzanie przebiegu zdarzeń wykorzystywane jest najczęściej w sprawach skoncentrowanych w czasie i przestrzeni, takich jak np. kradzież z włamaniem, podpalenie. Technikę wykorzystuje się przeważnie na miejscu zdarzenia. Stosuje się ją w stosunku do sprawców wrażliwych, którzy wiążą z przestępstwem negatywne odczucia - najczęściej młodocianych i kobiet ${ }^{36}$.

Obok wcześniej wymienionych technik emocjonalnych i racjonalnych występują także techniki określane mianem kontrowersyjnych.

32 K. Otłowski, Podejrzany w postępowaniu karnym: studium kryminalistyczne, Warszawa 1979, s. 92.

33 T. Hanausek, Kryminalistyka. Zarys wykładu, Kraków 2005, s. 82.

34 E. Gruza E., Ocena wiarygodności..., dz. cyt., s. 291.

35 W. Pływaczewski, G. Kędzierska, Lesykon policyjny, Szczytno 2001, s. 264.

36 W. Pasko-Porys, Przesłuchiwanie..., dz. cyt., s. 117. 
Małgorzata Zawartka - Taktyka i metody przeprowadzania...

Budzą one sprzeczne emocje w doktrynie ze względu na atmosferę, jaką pozwalają wykreować w trakcie przesłuchania.

Pierwsza z kontrowersyjnych technik określana jest skrótową nazwą „dobry-zły”. Opiera się na zmianie osób prowadzących przesłuchanie. Zmiana osób wprowadza atmosferę dekoncentracji, a także pozwala sądzić, że przesłuchanie nie skończy się, póki osoba przesłuchiwana nie poda interesujących informacji lub też nie przyzna się do winy ${ }^{37}$.

Przesłuchujący odgrywają rolę złego lub dobrego. Dobry wytwarza „sympatyczną”, wręcz rozluźniającą atmosferę, stara się wzbudzić zaufanie osoby przesłuchiwanej. Jeśli metody stosowane przez „dobrego” nie przyniosą oczekiwanych rezultatów, do akcji wkracza „zły”, który swoim zachowaniem pokazuje, że nie jest przyjaźnie nastawiony do przesłuchiwanego i nie zamierza traktować go z serdecznością38.

Kolejna z kontrowersyjnych technik opiera się na wywołaniu napięcia i stresu u osoby przesłuchiwanej. Technika ta dopuszcza przerywanie przesłuchania w chwilach, które wywołują napięcie ${ }^{39}$. Osoba przesłuchiwana gubi się wówczas w domysłach i traci pewność siebie. Kontynuując przesłuchanie, zmienia się jego taktykę, tak by zmusić osobę przesłuchiwaną do zastanowienia, zmiany taktyki, co wpływa na zmianę wcześniej obranej linii obrony ${ }^{40}$.

Innym sposobem wpływającym na wywołanie napięcia jest zadawanie pytań i niepozwalanie osobie przesłuchiwanej na pełnq odpowiedź ${ }^{41}$. Takie przerywanie bardzo często wyprowadza przesłuchiwanego $\mathrm{z}$ równowagi.

Ostatnią z budzących kontrowersje technik przesłuchania jest tzw. technika „wszechwiedzy”. T. Hanausek ocenia tę technikę jako kontro-

37 T. Hanausek, Kryminalistyka..., dz. cyt., s. 242.

38 B. Hołyst, Kryminalistyka, dz. cyt., s. 1121.

${ }^{39}$ E. Kurleto, $Z$ problematyki wykorzystania stresu psychologicznego $w$ trakcie przesłuchania podejrzanego, „Problemy Kryminalistyki” 1986, nr 171, s. 63.

40 T. Matysiak, Efektywność przesłuchania, „Służba MO” 1973, nr 97, s. 623.

41 E. Kurleto, $Z$ problematyki wykorzystania..., dz. cyt. s. 71. 
wersyjną ${ }^{42}$, jednak jeżeli dodać do określenia „wszechwiedza” określenie „pozorna”, to metoda ta przestaje być kontrowersyjną, a tym samym nie może być uznawana za naruszającą procedurę karną ${ }^{43}$.

Technika „wszechwiedzy” opiera się na znajomości jak największej ilości szczegółów dotyczących zdarzenia i samego świadka czy podejrzanego. Przesłuchanie prowadzone jest tak, by osoba przesłuchiwana odnosiła wrażenie, że przesłuchujący wie o niej wszystko. Celem przesłuchania jest wybadanie szczerości osoby przesłuchiwanej, bowiem wszystkie fakty dotyczące zdarzenia są już znane.

\section{Niedozwolone metody przesłuchiwania}

Niedozwolone sposoby przesłuchiwania pozostają w ścisłym związku z postawami osób przesłuchujących, które swoim działaniem i postawą godzą w swobodę i będącą jej ważnym elementem spontaniczność wypowiedzi przesłuchiwanego ${ }^{44}$.

Przesłuchanie może być prowadzone przy wykorzystaniu dowolnej metody, o ile nie powoduje ona naruszenia dwóch granic. Pierwszą $\mathrm{z}$ nich jest ograniczenie swobody wypowiedzi osoby przesłuchiwanej, wpływające na ograniczenie spontaniczności wypowiedzi. Druga granica wiąże się $\mathrm{z}$ wyłączeniem swobody wypowiedzi poprzez zastosowanie przymusu bądź groźby, które mają wymusić relację osoby przesłuchiwanej.

Podstawowym środkiem wyłączenia swobody wypowiedzi przesłuchiwanego, jak już zaznaczono, jest oddziaływanie za pomocą groźby i przymusu, jednak w szczególnych przypadkach jednakowy skutek mogą mieć inne naruszenia dyspozycji zawartych w art. 171 k.p.k. ${ }^{45}$.

42 T. Hanausek, Kryminalistyka..., dz. cyt., s. 245. Metodę wszechwiedzy określa za kontrowersyjną i mogącą być uznaną za niedopuszczalną w przesłuchaniu procesowym, co nie dotyczy czynności rozpoznawczo-operacyjnych.

43 W. Pasko-Porys, Przesłuchiwanie i wywiad..., dz. cyt., s. 119.

${ }^{44}$ R. Kaczor, Niedozwolone sposoby..., dz. cyt., s. 115.

45 T. Tyszkiewicz, Kodeks postępowania karnego z komentarzem, Kraków 2003, s. 444 . 
Małgorzata Zawartka - Taktyka i metody przeprowadzania...

Rozstrzygnięcie, czy wyjaśnienia bądź zeznania zostały złożone w wyniku niedozwolonego sposobu przesłuchiwania, opiera się na dyspozycjach zawartych w przepisach Kodeksu postępowania karnego, a zwłaszcza wspomnianego już art. 171.

Niektóre z użytych w przepisach pojęć są objaśnione za pomocą definicji legalnej zawartej w kodeksie karnym, odrębną grupę stanowią natomiast sposoby postepowania przy przesłuchaniu, które ustawodawca określa za pomocą języka potocznego ze względu na brak odpowiednika w regulacjach prawnych ${ }^{46}$.

Zgodnie z art. $171 \S 5$ niedopuszczalne jest „wpływanie na wypowiedzi osoby przesłuchiwanej za pomocą przymusu lub groźby bezprawnej”, stosowanie wobec osoby przesłuchiwanej „hipnozy albo środków chemicznych lub technicznych wpływających na procesy psychiczne osoby przesłuchiwanej albo mających na celu kontrolę nieświadomych reakcji jej organizmu w związku z przesłuchaniem”.

Za groźbę bezprawną uważa się groźbę, o której mowa w art. 190 k.k., jak i groźbę spowodowania postępowania karnego lub rozgłoszenia wiadomości uwłaczającej czci zagrożonego lub jego osoby najbliższej; nie stanowi groźby zapowiedź spowodowania postępowania karnego, jeżeli ma ona jedynie na celu ochronę prawa naruszonego przestępstwem.

Przymus w przeciwieństwie do groźby bezprawnej nie posiada definicji ustawowej. Zgodnie z definicją słownikową „przymus” oznacza: nacisk, presję wywieraną przez kogoś, zniewalanie kogoś do działania wbrew swej woli47. Czyn noszący znamię przymusu to stosowanie najczęściej środków oddziaływania fizycznego, czego ekstremalnym przykładem mogą być tortury ${ }^{48}$. Kodeks karny posługuje się zbliżonym znaczeniowo do pojęcia przymusu pojęciem przemocy ${ }^{49}$.

46 R. Kaczor, Niedozwolone sposoby..., dz. cyt., s.119.

47 E. Sobol (red.), Nowy słownik języka polskiego, Warszawa 2003, s. 803.

48 L. Gardocki, Prawo karne, Warszawa 1996, s. 68.

49 Pojęcie przemocy charakteryzuje m.in. przestępstwo z art. $191 \S 1$ k.k. polegające na stosowaniu przemocy lub groźby bezprawnej w celu zmuszenia innej osoby do określonego działania, zaniechania lub znoszenia. 
Ustawodawca nie podaje także legalnej definicji hipnozy. Jest ona w pewnym sensie opisana za pomocą działań analogicznych, tj. wykorzystywania środków chemicznych i technicznych, które wpływają na procesy psychiczne albo mają na celu kontrolę jego nieświadomych reakcji. Słownik języka polskiego definiuje hipnozę jako „stan pośredni między snem a jawą, wywołany przez sugestie drugiej osoby, w którym usypiany zachowuje swoją świadomość, jednocześnie poddając się woli hipnotyzera"50. Hipnoza jest jedną z metod psychologicznych, umożliwiającą nawiązanie kontaktu $\mathrm{z}$ badanym, a tym samym ułatwiającą poznanie jego stanu psychicznego, motywów, cech osobowości, itp. 51 .

Ze stosowaniem hipnozy w sądownictwie wiąże się bardzo poważne niebezpieczeństwo, gdyż wiadomo, że to, co dana osoba przypomniała sobie w hipnozie, skłonna jest traktować jako coś bardziej wiarygodnego, niż to, co przypomniała sobie bez hipnozy52.

W. Grzeszczyk wypowiada się przeciwko dopuszczalności stosowania hipnozy $w$ trakcie przesłuchania. Twierdzi on mianowicie, że art. $171 \S 5$ k.p.k. określa niedozwolone metody przesłuchania wpływające na procesy psychiczne przesłuchiwanej osoby, co powoduje, że ich stosowanie jest niedopuszczalne niezależnie od tego, czy w konkretnej sytuacji wyłączały swobodę wypowiedzi osoby przesłuchiwanej, czy też nie ${ }^{53}$.

Wyłączenie swobody wypowiedzi jest zależne od poziomu rozwoju umysłowego osoby przesłuchiwanej, a także aktualnej kondycji psychicznej, w jakiej znajduje się konkretna osoba. Osoba o pewnych właściwościach, obniżonym poziomie intelektualnym albo obniżonej sprawności wynikającej z przyczyn przejściowych, może nie być w stanie „obronić się” przed sugestiami przesłuchującego i potwierdzać to, co w typowych warunkach przesłuchania byłoby zanegowane.

50 E. Sobol (red.), Nowy słownik..., dz. cyt., s. 258.

51 S. Waltoś, Proces karny: zarys systemu, Warszawa 2005, s. 368.

52 J. Wójcikiewicz, J. Siuta, Hipnoza kryminalna, Kraków 1999, s. 29.

53 W. Grzeszczyk, Kodeks postępowania karnego. Komentarz, Warszawa 2008, s. 165. 
Małgorzata Zawartka - Taktyka i metody przeprowadzania...

W takich przypadkach również pytania sugerujące mogą wyłączyć swobodę wypowiedzi przesłuchiwanego ${ }^{54}$.

Zapewnienie swobody wypowiedzi osoby przesłuchiwanej gwarantuje prawną skuteczność przesłuchania. Swoboda wypowiedzi oznacza bowiem, że osoba przesłuchiwana ma możliwość decydowania własną wolą o treści składanej wypowiedzi i nic nie krępuje go w formułowaniu tych wypowiedzi ${ }^{55}$.

Obok kryteriów prawnych warunkujących poprawność i ważność przeprowadzonego przesłuchania funkcjonują także kryteria etyczne, których należy przestrzegać, przystępując do przesłuchania.

Ustawodawca, zdając sobie sprawę z tego, że regulacja prawna ma niewystarczającą pojemność, stanowi normy prawne, które odsyłają do kryteriów pozaprawnych. Nakłada obowiązek posługiwania się przy ocenie dowodów zasadami wiedzy i doświadczenia życiowego oraz zasadami prawidłowego rozumowania (art. 7 k.p.k.).

W samym k.p.k. nie sposób znaleźć odesłania do moralności, mającej obligować do postępowania etycznego w trakcie gromadzenia materiału dowodowego ${ }^{56}$.

Chociaż kwestia etycznego postępowania i prowadzenia przesłuchania nie wynika wprost z k.p.k., to jest uwzględniona w aktach prawnych niższej rangi, a także w standardach i wewnętrznych regulaminach jednostek odpowiedzialnych za przesłuchanie świadka lub oskarżonego.

Komendant Główny Policji wystosował wytyczne, które dokładnie określają etyczne aspekty przeprowadzenia przesłuchania:

„§62. 1. Podczas swobodnej wypowiedzi świadka niedopuszczalne jest:

- przerywanie toku wypowiedzi świadka, chyba że wypowiedź ta w szerokim zakresie wykracza poza granice określone celem przesłuchania;

- okazywanie zniecierpliwienia, ponaglanie w celu przyspieszenia relacji;

- rozpraszanie świadka, prowadzenie rozmowy z innymi osobami;

\footnotetext{
${ }^{54}$ R. Kaczor, Niedozwolone sposoby..., dz. cyt., s.116.

55 T. Tyszkiewicz, Kodeks.., dz. cyt., s. 439.

56 R. Kaczor, Niedozwolone sposoby.., dz. cyt., s. 117.
} 
- pouczanie lub ocenianie świadka;

- przedstawianie własnego punktu widzenia lub własnej oceny zdarzeńn"57.

Za przykład zachowań określanych jako nieetyczne i zarazem niedopuszczalne przyjmuje się m.in. zwracanie się do przesłuchiwanego „po nazwisku” lub „przezwiskami” o negatywnym nacechowaniu; słuchanie wypowiedzi w taki sposób, by osoba mówiąca dostrzegła, że traktujemy ją jako kłamcę; wykorzystywanie śmiechu dla zdyskredytowania, zlekceważenia wypowiedzi osoby przesłuchiwanej58.

Analizując orzecznictwo Sądu Najwyższego i innych sądów, można dostrzec, jakie zachowania osób prowadzących przesłuchanie lub sytuacje, w jakich dochodziło do przesłuchania, zostały uznane za zgodne bądź niezgodne z obowiązującą zasadą swobody wypowiedzi. Sąd Apelacyjny w Katowicach wydał wyrok, w którym stwierdzono, że: „podanie świadkowi kawy, papierosów czy nawet leku uspokajającego nie jest środkiem wpływającym na procesy psychiczne świadka, czy wypełniającym istotę przymusu psychicznego, o jakim stanowi przepis art. $171 \S 5$ k.p.k." 59. Sąd Najwyższy w swoim postanowieniu stwierdził, że:

(...) z treści art. $171 \S 7$ k.p.k. nie wynika, aby wyłączenie swobody wypowiedzi musiało być spowodowane przez organ procesowy. Wprawienie się przez samego świadka (czy też oskarżonego) w stan nietrzeźwości, ograniczający, a nawet czasami znoszący, swobodę wypowiedzi, rozumianą jako zdolność panowania nad własną wolą przy ich formułowaniu, stanowi przeszkodę wykluczającą przesłuchanie go w okresie pozostawania pod działaniem alkoholu. Trzeba wyraźnie stwierdzić, że organowi procesowemu nie wolno wykorzystywać stanu upojenia alkoholowego przesłuchiwanego, w którym o nieskrępowanym wyrażaniu swoich myśli nie może być mowy 60 .

57 Zarządzenie nr 1426 Komendanta Głównego Policji z dnia 23 grudnia 2004 r. w sprawie metodyki wykonywania czynności dochodzeniowo-śledczych przez służby policyjne wyznaczone do wykrywania przestępstw i ścigania ich sprawców (Dz. Urz. KGP z dnia 10 stycznia 2005 r.).

58 Z. Nęcki, Negocjacje w biznesie, Kraków 1991, s. 77.

59 Wyrok SA w Katowicach z dnia 17 stycznia 2007 r., sygn. II AKa 421/06, KZS 2007, nr 5, poz. 79.

60 Postanowienie SN z dnia 26 listopada 2003 r., sygn. III KK 506/02, LEX nr 82319. 
Małgorzata Zawartka - Taktyka i metody przeprowadzania...

Sąd Apelacyjny od dawna aprobuje stosowane przez pracowników śledczych zachęcanie sprawców przestępstw, by mówili prawdę w wyjaśnieniach. Dopóki nie popełnia się przy tym nadużyć, nie składa obietnic niemożliwych do spełnienia, nie oszukuje co do stanu innych dowodów, nie zmusza przesłuchiwanego itd., nie ma w tym niczego zdrożnego. Zachęty takie są bowiem wyrazem dążenia zarówno do uzyskania większej ilości dowodów, jak i do wykrycia prawdy, bez której nie może być sprawiedliwości. Jest to zresztą korzystne zarówno dla sprawców, którzy zyskują poważną okoliczność łagodzącą kary, jak i dla oszczędzenia procesowi komplikacji dowodowych, nakładów czasu i środków ${ }^{61 .}$

Zgodnie z dyspozycjami zawartymi w art. $171 \S 7$ wyjaśnienia, zeznania i oświadczenia złożone w warunkach, które ograniczają lub wyłączają swobodę wypowiedzi lub też zostały uzyskane wbrew zakazom wymienionym w $§ 5$, nie mogą stanowić dowodu. Dowody pozyskane w niedozwolony sposób uważane są za nieistniejące.

Dyspozycje zawarte w przepisach jasno określają, jakie warunki muszą zostać spełnione, by przesłuchanie można było uznać za ważne, jednak zdarzają się sytuacje, w których tylko zastosowanie niedozwolonych metod pozwoli osiągnąć cel przesłuchania. Jak stwierdził P. Bobbitt:

W pewnych wyjątkowych sytuacjach, które mogą się zdarzyć jedynie bardzo, bardzo rzadko - ale jednak się zdarzają - trzeba będzie zagrozić torturami albo je zastosować. Na przykład, gdy dzięki temu będziemy mogli ocalić życie tysięcy ludzi albo gdy pojawi się inna bardzo ważna, wyjątkowa przyczyna. To nie oznacza jednak, że uznamy tortury za legalne. Konieczne będzie złamanie prawa, żeby je zastosować. Zupełnie jak wtedy, gdy ktoś łamie prawo, przejeżdżając na czerwonym świetle i przekraczając dozwoloną prędkość, bo wiezie do szpitala żonę, która właśnie zaczęła rodzićć2.

W niektórych sytuacjach oddziaływanie na podejrzanego poprzez zastosowanie niedozwolonych sposobów przesłuchania pozwoli zapobiec realizacji zamiarów grupy przestępczej, do której przynależy.

61 Wyrok SA w Katowicach z dnia 5 czerwca 1996 r., sygn. II AKa 125/06, KZS 1996, nr 5-6, poz. 68.

62 Świat wkracza w epokę państwa rynkowego, „Tygodnik Idei. Europa”, nr 26 (221) z dnia 28 czerwca 2008 r., s. 9. 
Wątpliwe, by w społecznej ocenie funkcjonariusz stosujący niedozwolone sposoby przesłuchania powinien zostać ukarany ${ }^{63}$.

\section{Zakończenie}

Dobór odpowiedniej metody oraz taktyki przesłuchania decyduje o skuteczności przeprowadzonego dowodu, dlatego tak ważne jest odpowiednie wyselekcjonowanie oraz przeszkolenie osób odpowiedzialnych za przeprowadzenie dowodu z osobowego źródła dowodowego, jakim jest m.in. świadek czy oskarżony. Prowadzący przesłuchanie musi postępować zgodnie z regułami oraz celami przesłuchania, a także ocenić, jaka taktyka przesłuchania pozwoli pozyskać wartościowy materiał dowodowy. W ocenie istotną rolę odgrywa znajomość psychologii, a także zdolność do empatii. Prócz taktyki istotną rolę odgrywa dobór samej metody przesłuchania. Zależnie od indywidualnych predyspozycji osoby przesłuchiwanej dobiera się metodę, która pozwoli zbudować zaufanie na linii przesłuchujący - przesłuchiwany, a także zapewni jak największy komfort psychiczny, niezwykle istotny przy przesłuchiwaniu świadka, a zwłaszcza świadka małoletniego.

\section{Bibliografia:}

Chudy W., Kłamstwo jako metoda. Esej o społeczeństwie i kłamstwie, Warszawa 2007.

Cieślak M., Polska procedura karna. Podstawowe założenia teoretyczne, Warszawa 1984.

Ciosek M., Psychologia sq̨dowa i penitencjarna, Warszawa 2001.

Gadomska-Radel A., Przesłuchanie dziecka jako ofiary i świadka przestępstwa w procesie karnym, Warszawa 2015.

Gardocki L., Prawo karne, Warszawa 1996.

Gruza E., Ocena wiarygodności zeznań świadków w procesie karnym. Problematyka kryminalistyczna, Kraków 2003.

${ }^{63}$ R. Kaczor, Niedozwolone sposoby..., dz. cyt., s. 130. 
Małgorzata Zawartka - Taktyka i metody przeprowadzania...

Gruza E., Goc M., Moszczyński J., Kryminalistyka - czyli rzecz o metodach śledczych, Warszawa 2008.

Grzeszczyk W., Kodeks postępowania karnego. Komentarz, Warszawa 2008.

Gulla B., Niewiadomska I., Wysocka-Pleczyk M. (red.), Białe plamy w psychologii sq̨dowej, Kraków 2010.

Gurgul J, Znaczenie taktyki kryminalistycznej w realizacji zasad postępowania karnego, „Problemy Kryminalistyki” 1985, nr 168.

Hanausek T. Kryminalistyka. Zarys wykładu, Kraków 2005.

Hanausek T., Braki pamięciowe w zeznaniach świadka, „Problemy Kryminalistyki" 1969, nr 82.

Hołyst B., Kryminalistyka, Warszawa 2004.

Hołyst B., Psychologia kryminalistyczna, Warszawa 2004.

Kaczor R., Niedozwolone sposoby przesłuchania, „Prokuratura i Prawo” 2009, nr 3.

Kurleto E., Z problematyki wykorzystania stresu psychologicznego $w$ trakcie przesłuchania podejrzanego, „Problemy Kryminalistyki” 1986, nr 171.

Kwiatkowska-Darul V., Przesłuchanie małoletniego świadka w polskim procesie karnym, Toruń 2007.

Marszał K. (red.), Proces karny, Katowice 2005.

Marten Z., Psychologia zeznań, Warszawa 2012.

Matysiak T., Efektywność przesłuchania, „Służba MO” 1973, nr 97.

Nęcki Z., Negocjacje w biznesie, Kraków 1991.

Niezgoda Z., Kryminalistyczne aspekty przesłuchania świadka, „Prokuratura i Prawo" 2007, nr 2.

Otłowski K., Podejrzany w postępowaniu karnym: studium kryminalistyczne, Warszawa 1979.

Pasko-Porys W., Przesłuchiwanie i wywiad. Psychologia kryminalistyczna, Warszawa 2007.

Pływaczewski W., Kędzierska G., Lesykon policyjny, Szczytno 2001.

Reed L.D., Podatność dzieci na sugestię: ustalenia badawcze i ich implikacje dla przesłuchiwania dzieci, „Dziecko krzywdzone. Teoria. Badania. Praktyka" 2004, nr 6.

Sobol E.(red.), Nowy słownik języka polskiego, Warszawa 2003.

Świat wkracza w epokę państwa rynkowego, „Tygodnik Idei. Europa”, nr 26 (221) z dnia 28 czerwca 2008.

Tyszkiewicz T., Kodeks postępowania karnego z komentarzem, Kraków 2003. 
Waltoś S., Proces karny: zarys systemu, Warszawa 2005.

Wójcikiewicz J., Siuta J., Hipnoza kryminalna, Kraków 1999. 